\title{
THOMAS PAINE AND DEMOCRATIC RELIGION IN AMERICA
}

\author{
RYAN PATRICK HOSELTON
}

\begin{abstract}
This essay examines the democratic impulses that shaped Thomas Paine's vision for a religious revolution. Many historical treatments have recognized the central role that the themes of equality and freedom played in his political ideology. This study expands on this analysis by demonstrating how Paine grounded his religious beliefs in the same soil, advocating for Americans to extend the same democratic ideals of the political revolution to reform religion. Despite the irony that most Americans who supported Paine's political vision rejected his religious ideas, many orthodox religious leaders adapted their beliefs and practices to the same democratic impulses as Paine. Thus, contrary to many treatments that simplistically juxtapose Paine and America's faithful, this essay contends that both ultimately contributed to many of the same underlying democratic shifts in religious and cultural authority in late eighteenth- and early nineteenth-century America.
\end{abstract}

Keywords: United States, Thomas Paine, American religion, democracy, evangelicalism

DOI: $10.14712 / 23363231.2016 .1$

\section{Introduction}

Alexis de Tocqueville, the French political thinker and one of America's most famous nineteenth-century visitors, found it especially unique and striking how in America, "two perfectly distinct elements that elsewhere have often made war with each other $[\ldots]$ have succeeded in incorporating somehow into another and combining marvelously. I mean to speak of the spirit of religion and the spirit of freedom." ${ }^{1}$ He was not the first nor the last observer of America to marvel at its people's simultaneous devotion to liberty and religiosity. On the surface, it seems

1 Alexis de Tocqueville, Democracy in America, ed. and trans. Harvey Claflin Mansfield and Delba Winthrop (Chicago, IL: University of Chicago Press, 2000), 43. 
these two impulses went effortlessly hand in hand in America's early republic. However, as some studies have demonstrated, a closer look reveals a complex shift of authority, as many influential Protestant leaders adapted their language, practices, and theology to evolving democratizing impulses - namely, equality rooted in common creation, universal human reason, and self-governing moral agency. ${ }^{2}$

The objective of this essay is to expand on this body of literature by highlighting an important historical connection between how Protestants and the Deist Thomas Paine (1737-1809) ${ }^{3}$ mutually shaped democratic religion in America. Drawing from developments in postsecular theory, this paper seeks to contribute to the reassessment of the relationship between Enlightenment and religious forces and its significance for the historical formation of cultural, intellectual, and religious realities in modern America. ${ }^{4}$ Contrary to diachronic and teleological inter-

2 See for example Nathan Hatch, The Democratization of American Christianity (New Haven, CT: Yale University Press, 1989); Mark Noll, America's God (New York: Oxford University Press, 2002); E. Brooks Holifield, The Gentlemen Theologians (Durham, NC: Duke University Press, 1978; reprint, Eugene, OR: Wipf \& Stock, 2007); Thomas Kidd, God of Liberty: A Religious History of the American Revolution (New York: Basic Books, 2010).

3 For biographies on Paine, see David Powell, Tom Paine: The Greatest Exile (New York, NY: St. Martin's Press, 1985); John Keane, Tom Paine: A Political Life (Boston, MA: Little, Brown and Company, 1995); and for an old but classic work, see Moncure Daniel Conway, The Life of Thomas Paine (New York, NY: G. P. Putnam's Sons, 1892). On the intellectual context of the Revolutionary era and Deism, see Henry F. May, The Enlightenment in America (New York, NY: Oxford University Press, 1976); Gary Wills, Inventing America: Jefferson's Declaration of Independence (New York, NY: Oxford University Press, 1979); Morton White, The Philosophy of the American Revolution (New York, NY: Oxford University Press, 1978); and Kerry S. Walters, The American Deists: Voices of Reason and Dissent in the Early Republic (Lawrence, KS: University Press of Kansas, 1992). On Paine's thought, see Gregory Claeys, Thomas Paine: Social and Political Thought (Boston, MA: Unwin Hyman, 1989); Eric Foner, Tom Paine and Revolutionary America (New York, NY: Oxford University Press, 1976); Alfred Owen Aldridge, Thomas Paine's American Ideology (Newark, DE: University of Delaware Press, 1984); and Bruce Kuklick, ed., Thomas Paine (Burlington, VT: Ashgate, 2006).

4 Sarah Rivett's assessment of the implications of the recent "religious turn" - i.e. the scholarly revival of interest in religion upon realizing, in the wake of $9 / 11$, that the secularization thesis failed and American society remains deeply religious - for early American studies marks a needed step in this direction. According to Rivett, scholars in a postsecular age must "step outside this binary of secular versus religious" and reevaluate religious cultures on their own terms if they wish to understand the role of religion as a historical and social force in America. The historiography of the Enlightenment plays a central role in this revision: "The religious turn, rapidly unfolding into an era of postsecular theory, challenges our assumption that the Enlightenment replaced religion as a dominant or mainstream explanatory mechanism." Indeed, while the "Enlightenment remains the antecedent to our modern myth of secularization," the rise of "evangelicalism offers lasting evidence that this myth bears little resemblence to historical fact." Nonetheless, many scholars continue to approach the relationship between the Enlightenment and American religious history with a "telos of secularization," a "perspective that organizes historical analysis according to either a causal interpretation" in which the Enlightenment secularized religion, or as "formally distinct registers," which presents the Enlightenment and religious cultures as unrelated or polarized threads. Such 
pretations that harness Paine's legacy to trace the prehistory of secular America today by juxtaposing Paine and America's faithful according to misleading binary oppositions (i.e. sacred vs. profane, religious tradition vs. modern freethinking), this essay presents them as coinciding historical forces in molding many of the same underlying democratic shifts in religious and cultural authority in late eighteenth- and early nineteenth-century America. Whereas several studies have qualified this secularization narrative by highlighting the overlap between the political principles of Enlightenment figures and Protestants, the comparison has seldom been extended to theology. Most continue to interpret his controversial work, The Age of Reason (1794), as a vitriolic polemical manual promoting Deism, attacking supernatural religion, and invoking the harsh condemnation of America's faithful. Though not inaccurate per se, using this text as a representative example of the clash between Enlightenment ideals and Christian belief is incomplete and consequently overemphasizes the differences between Paine and his American orthodox critics while obscuring the correspondence in their agendas to reshape religion around democratic principles. ${ }^{5}$ Although Paine and Protestant writers reached very different theological conclusions in their reactions to their shifting cultural context, the similarities in their presuppositions and methods show how both contributed to significant deviations from pre-Revolutionary forms of American religious expression. ${ }^{6}$

Since the available literature has largely explored the cultural, political, and religious dimensions of the democratization of religion in America, the first two

approaches deepen misleading narratives of secularization that have little correspondence with religious and cultural realities both in the eighteenth century and today. See Sarah Rivett, "Early American Religion in a Postsecular Age," MLA 128.4 (2013), 993-94.

5 This interpretation is exacerbated by most of Paine's biographers and others who ascribe his most significant contributions to his political thought. Thus, while many treatments have drawn considerable attention to how Paine grounded his political revolutionary thought in the notion of human equality, few have explored how he planted his religious revolution in the same soil. See among others Gordon Wood, The Idea of America (New York, NY: Penguin, 2011), 215; and Jack Fruchtman, Jr. "Nature and Revolution in Paine's Common Sense," History of Political Thought 10 (1989): 421-38. Ian Harris' work is a notable exception: "Paine and Burke: God, Nature and Politics," in Public and Private Doctrine: Essays in British History presented to Maurice Cowling, ed. Michael Bentley (Cambridge, UK: Cambridge University Press, 1993), 34-62. In his ninetieth footnote, Harris explains the scant attention given to the relationship between Paine's theology and his social and political principles. Despite the fact that he wrote this in 1993, I have not found much improvement since then. Most works treat Paine's religious ideas as an example of Deism while neglecting how they impact his general thinking and agenda. By contrasting Paine and Burke, Harris more adequately acknowledges the role that equality played in both Paine's political and religious thought.

6 See James C. Turner, Without God, Without Creed: The Origins of Unbelief in America (Baltimore, MD: Johns Hopkins University Press, 1986), 73-113. 
sections of this essay briefly expand on these works by examining the overlap between how Protestants and Paine extended democratic values to religious belief. The last part then contributes a theological reading of his religious writings, primarily The Age of Reason, in order to more closely analyze the central points of his vision for a democratic religion. The limited scope of this paper is thus not to provide a comprehensive survey of democratic thought and religion in early America but rather a finite reconceptualization of Paine's religious thought from a postsecular perspective.

\section{American Democratic Orthodoxy}

Samuel Adams voiced the sentiment of many Americans in his reaction to Paine's controversial tract, The Age of Reason. "Your Common Sense, and your Crisis, unquestionably awakened the public mind, and led the people loudly to call for a declaration of national independence," Adams wrote to Paine. "But when I heard that you had turned your mind to a defense of infidelity, I felt myself much astonished and more grieved, that you had tempted a measure so injurious" to the "true interest of so great a part of the citizens of the United States. The people of New England, if you will allow me to use a Scripture phrase, are fast returning to their first love." 7 Many Americans enthusiastically received Paine's political revolution as expressed in Common Sense, the bestselling pamphlet of the Revolutionary period. ${ }^{8}$ However, with the exception of some Deist and humanist societies, most Americans followed the orthodox clergy in censuring his religious revolutionary vision. ${ }^{9}$ The simultaneous acceptance of Paine's political revolution and denunciation of his religious ideas was ironic - Paine would have deemed it inconsistent - since he believed that he grounded both on the same democratic principles that they commonly embraced.

7 Samuel Adams to Thomas Paine, November 30, 1802. Quoted from Matthew Harris and Thomas Kidd, eds., The Founding Fathers and the Debate Over Religion in Revolutionary America: A History in Documents (New York, NY: Oxford University Press, 2011), 175. Likewise, Ebenezer Bradford, an American clergyman, simultaneously praises Paine's political revolutionary works like Common Sense while denouncing his religious works. See Ebenezer Bradford, "Mr. Thomas Paine's trial, being an examination of his Age of reason" (Boston: Printed by Isaiah Thomas and Ebenezer T. Andrews, 1795), 12-13.

8 Homer L. Calkin, "Pamphlets and Public Opinion During the American Revolution," Pennsylvania Magazine of History and Biography 64 (1940): 38-40. John Adams commented that Common Sense "was received in France and in all Europe with Rapture." From the entry for February 11, 1779, in Lyman H. Butterfield, ed., Diary and Autobiography of John Adams, vol. 2 (Cambridge, MA: Belknap, 1961), 351.

9 See Holifield, Gentlemen Theologians, 52-57. 
Many American Protestants contributed to the same political revolutions as Paine, but they believed that the anthropological principles that ignited these political revolutions would produce a very different religious revolution than what Paine envisioned. Benjamin Rush, for example, considered "Christianity as the strong ground of republicanism," not Deism. For Rush, "republican liberty and equality," and thus opposition to monarchy, were inherent to Christian belief. Hence, he pleaded for "republicanism to ally itself to the Christian religions to overturn all the corrupted political and religious institutions in the world." 10 While many American Protestants, such as Yale President Ezra Stiles and the Baptist minister Isaac Backus, disagreed about whether Federalist or Anti-Federalist politics worked best with popular democracy, they agreed for the most part that Christianity complemented republican principles of human equality best. ${ }^{11}$ This sentiment marked a shift away from the hierarchical social ideals of seventeenth-century Puritan New England, as articulated by John Winthrop: "God Almighty [...] has so disposed of the condition of mankind, as in all times some must be rich and some poor, some high and eminent in power and dignity; others [lowly] and in subjection." 12 As Thomas Kidd notes, the "Revolution had inaugurated a new era in the Christian view of man, in which equality by creation became the guiding principle." 13 Whereas many Puritans focused on hierarchical texts in the Bible when it came to social structure, much of the Christian political discourse following the Revolution pointed frequently to more egalitarian passages like Galatians 3:28 and Acts 17:26. ${ }^{14}$

In the populist developments of the first Great Awakening, there were notable precedents for many of the democratizing shifts in nineteenth-century American religion. Also, many religious leaders in the mid-eighteenth century employed a republican rhetoric in their sermons and writings that helped pave the way for

${ }^{10}$ Rush claimed that he had suggested the title of Common Sense to Paine. Rush to Jefferson, 22 August, 1800, in Letters of Rush, 2:820-21. Quoted in Noll, America's God, 65.

${ }^{11}$ See Ezra Stiles, The United States elevated to glory and honor (Worchester, MA: Printed by Isaiah Thomas, and sold at his book-store, 1785); and Isaac Backus, Government and Liberty Described (1778), in Isaac Backus on Church, State, and Calvinism: Pamphlets, 1754-1789, ed. William G. McLoughlin (Cambridge, MA: The Belknap Press of Harvard University Press, 1968), 345-65.

12 John Winthrop, A Model of Christian Charity, in The Puritans, ed. Perry Miller and Thomas Johnson (New York: Harper and Row, 1963), 1:195.

13 Kidd, God of Liberty, 144. Kidd offers helpful insight into the role of human equality in the Revolution in chapter 7, "God Has Made of One Blood All Nations of Men."

${ }^{14}$ Kidd, God of Liberty, 133-34. The KJV translations of these verses are: Gal. 3:28: "There is neither Jew nor Greek, there is neither bond nor free, there is neither male nor female: for ye are all one in Christ Jesus." Acts 17:26: "And [God] hath made of one blood all nations of men for to dwell on all the face of the earth." 
America's faithful to embrace the Revolution, but these ideas had not yet significantly redefined their theology. During and after the Revolution, however, many ministers infused their theology with democratic themes of liberty, human agency, and a greater confidence in natural human faculties, adapting their doctrines to a new context. Religious literature - especially doctrinal polemics - increasingly appealed to self-evident principles, reason, consciousness, and common sense alongside Scripture.

Many of these democratizing impulses culminated most dramatically - at least among evangelicals - in America's most influential nineteenth-century theologian and revivalist, Charles Finney (1792-1875). Finney - who would have rejected Paine as an infidel - likewise reshaped orthodox Protestant beliefs and practices around democratic principles. In his Lectures on Systematic Theology (1846), he framed his theological categories as extensions of the moral government of God, highlighting themes of justice, free will, equality, and moral agency. Due to his more optimistic anthropology, he denied original sin and redefined spiritual regeneration not as a radical change in human nature but as a "change from selfishness to disinterested benevolence." 15 Seeking to present a universally fair theology, he radically departed from central Calvinist notions by ascribing human moral agency with complete freedom and the ability to fulfill moral duties to God: "The moral government of God assumes and implies the liberty of the human will, and the natural ability of men to obey God." 16 These democratizing modifications had significant implications for his understanding of religious practice. In his earlier work, Lectures on Revivals of Religion (1835), Finney declared, "Religion is the work of man," for there "is nothing in religion beyond the ordinary powers of nature." 17 In order to inspire religious vitality, Finney argued, ministers must employ ordinary means like holding protracted revivals, developing a persuasive rhetoric, and aggressively urging men and women to exercise their reason and will to choose Christianity. Among other democratic measures, he ascribed greater religious authority to lay believers, allowed women to lead religious meetings, established voluntary societies to reform morality, and he urged ministers to dress the same as their parishioners in order to avoid the appearance of inequality. ${ }^{18}$

15 Charles G. Finney, Finney's Systematic Theology, ed. by L. G. Jr. Parkhurst (Minneapolis, MN: Bethany House Publishers, 1994), 284. This edition is taken from the unabridged 1878 edition of his Lectures on Systematic Theology.

${ }^{16}$ Finney, Systematic Theology, 307.

17 Charles G. Finney, Lectures on Revivals of Religion (New York: Leavitt, Lord \& Co., 1835), 9, 12.

18 Finney, Revivals of Religion, 232-40. 


\section{Thomas Paine's Democratic Religious Revolution}

Although evangelicals and Deists drew very different conclusions regarding religious belief and practice, their shared democratic principles contributed to the same momentous shift of religious authority in the American religious context. In 1776, Paine articulated his revolutionary vision in a pamphlet arguing for the justification of an American political revolution based on Common Sense. The idea that lent his political discourse its revolutionary edge was the equality of mankind: "the exalting [of] one man so greatly above the rest cannot be justified on the equal rights of nature." The claim to royal prerogative on the basis of hereditary privilege fundamentally violated human equality: "Mankind being originally equals in the order of creation, the equality could only be destroyed by some subsequent circumstance [...] that is, the distinction of men into kings and subjects." Hence, "no one by birth could have a right to set up his own family in perpetual preference to all others forever," not even King George III. Paine had convinced many Americans that living under illegitimate authority demeaned their humanity, calling upon them to enact a democratic political revolution to restore their natural rights: "We have it in our power to begin the world over again." His confidence in human nature was universal. He equated "the cause of America" to "the cause of all mankind," because liberty was a right for "every man to whom nature has given the power of feeling," regardless of "class."19 Paine channeled an Enlightenment understanding of human nature into what E. P. Thompson terms a "new rhetoric of radical egalitarianism." 20 If all humankind was equal, as Enlightenment philosophers like Locke and Jean-Jacques Burlamaqui maintained, then Paine concluded that not only government, but also religion should look very different. ${ }^{21}$

Paine defended the French Revolution with the same reasoning he employed to promote the American Revolution. In the Rights of Man (1791), Paine developed his views on human nature more fully in order to counter the Englishman

19 Thomas Paine, Common Sense, in Paine: Political Writings, ed. Bruce Kuklick (Cambridge, UK: Cambridge University Press, 2000), 9, 8, 11, 44, 2.

${ }^{20}$ Edward Palmer Thompson, The Making of the English Working Class (London: Victor Gollancz, 1963), 103, 121.

${ }^{21}$ Gordon Wood writes, "The belief in the equal moral worth and equal moral authority of every individual was the real source of both Jefferson's and Paine's democratic equality." See Wood, The Idea of America, 216-17. Although Wood correctly recognizes that Paine drew important implications about social harmony and minimal government from his doctrine of equality, he omits any mention of how Paine extended these implications to his religious views. 
Edmund Burke's attack on the French Declaration of the Rights of Man. ${ }^{22}$ Paine once again based his apology on human equality: since "every individual is born equal in rights with his contemporary," then "civil power [...] is made up of the aggregate" of all humankind. ${ }^{23}$ The exchange between Burke and Paine displays how late eighteenth-century political theory was heavily intertwined with theology. In contrast to Burke, who argued that the divine order sanctioned certain social inequalities, Paine contested that the Creator endowed equal social rights to every human being at creation. Any claim to privileged authority not only undermined true humanity; it also subverted God's egalitarian creation order. Since every person shared a common origin and Creator, all possess the same natural and civil rights. Owen Aldridge's assessment thus overlooks the importance of Paine's religious thought and its connection to his overall democratic and political ideology: "the religious references in Common Sense are superfluous to Paine's political system, which could stand by itself, as it does in Rights of Man. In this sense, there is no essential connection between Paine's religion and his politics." 24

By 1793, when Paine wrote Part I of The Age of Reason, he had anticipated that "a revolution in the system of government would be followed by a revolution in the system of religion." 25 Not "until the system of government should be changed," Paine asserted, would religious traditions and authorities "be brought fairly and openly before the world" and "a revolution in religion would follow."26 He maintained this confidence because he had based his vision for a religious revolution on the same democratic premises as his political revolution. Just as King George III had no inherent authority to rule over anyone, neither did any religious system have authoritative knowledge or privileged access to God. For Paine, if the equality of mankind entailed the democratization of politics, it also entailed the democratization of religion.

22 The work that Paine responded to was Burke's Reflections on the Revolution in France. On the differences between Burke and Paine on religion and politics, see Harris, "Paine and Burke," 34-62.

23 Paine, Rights of Man, Part I, in Paine: Political Writings, ed. by Bruce Kuklick (Cambridge, UK: Cambridge University Press, 2000), 85, 87.

24 Aldridge, Paine's American Ideology, 102.

25 Thomas Paine, The Age of Reason, in Paine: Political Writings, ed. Bruce Kuklick (Cambridge, UK: Cambridge University Press, 2000), 269. Paine published The Age of Reason in two parts: Part I in 1794, and Part II in 1795. As Paine wrote Part I, he did not have access to a Bible. Thus, he wrote Part II to extend his criticisms on the Old and New Testament texts once he obtained one (after release from prison). This essay focuses on Part I because it expresses his religious revolutionary vision more thoroughly. Nonetheless, although this essay does not address this point in depth, Paine's democratic ideals deeply impacted his interpretation and use of Scripture.

26 Ibid., 268. 
While many Americans seized the momentum of the political revolution for Christianity, multitudes in France harnessed it for atheism. Paine addressed The Age of Reason to his fellow American citizens, but he aimed to convert French atheists to his religious revolution as well. While in France, Paine witnessed the "total abolition of the whole national order of priesthood and of everything appertaining to compulsive systems of religion and [...] articles of faith." 27 Political and religious revolutions went hand in hand in France, but Paine found the militant atheism behind it a threat to establishing true democracy, morality, and social order. In 1793, the French beheaded their royalty and transformed Notre Dame into a Temple of Reason. For Paine, this was not the kind of religious revolution that should follow a proper democratic political revolution. ${ }^{28}$ The circumstances in France assured Paine that the vision he promoted in The Age of Reason was "exceedingly necessary," lest "in the general wreck of superstition, of false government, and false theology, we lose sight of morality, of humanity, and of the theology that is true." 29 In a letter to Samuel Adams, Paine explained that he wrote The Age of Reason partly because "the people of France were running headlong into atheism," and he aimed to "stop them in that career, and fix them to the first article of every man's creed, who has any creed at all, I believe in one God." 30 Thus, interpretations that portray Paine's significance and contribution as an anti-religious, secularizing force deeply conflict with his own statements about the importance of religious belief for achieving true social democracy.

Paine envisioned a dramatically different revolution in religion than the Christians and the atheists. For Paine, formal religion and atheism undermined the equality of mankind. Christianity discriminated against men and women by insisting on exclusive revelation and salvation, while atheism subverted the basis of equality by negating the Creator, the giver of natural rights. Neither Christianity nor atheism held promise as a sufficient social companion to the egalitarian political revolution that Paine espoused. In a lecture to The Society of Theophilanthropists at Paris, Paine contended, "Religion has two principal enemies, Fanaticism and Infidelity, or that which is called Atheism. The first requires to be combated by reason and morality, the other by natural philosophy." ${ }^{31}$ Christianity, Judaism, and

27 Ibid., 267.

${ }^{28}$ John Keane, Tom Paine: A Political Life (Boston: Little, Brown and Company, 1995), 393-96.

29 Paine, Age of Reason, 267.

30 Thomas Paine, "Letter to Samuel Adams," in The Complete Religious and Theological Works of Thomas Paine (New York, NY: Peter Eckler, Publisher, 1895), 375.

31 Thomas Paine, "A Discourse Delivered to The Society of Theophilanthropists at Paris," in The Complete Religious and Theological Works of Thomas Paine (New York: Peter Eckler, Publisher, 1895), 300. 
"Mahometism" exercised a form of oppression that was just as egregious as that of the political tyrants overthrown in the revolutions, Paine submitted.

\section{Paine's Democratic Theology}

In The Age of Reason, Paine grounded his democratic theology in a confession of faith comprised of two articles: "I believe in one God, and no more; and I hope for happiness beyond this life. I believe in the equality of man, and I believe that religious duties consist in doing justice, loving mercy, and endeavoring to make our fellow-creatures happy." 32 First, Paine's belief in God legitimated the democratization of both civil and religious rights because God created everyone with equal natural rights. Second, human equality entailed replacing political and religious tyranny with egalitarian, universal, and democratic beliefs and practices. Paine expanded on his egalitarian understanding of God and humanity in order to promote new ways of thinking about religious knowledge, God, redemption, and morality in more democratic terms.

First, Paine sought to reshape traditional understandings of religious knowledge and revelation based on his driving theological principle of common creation. ${ }^{33} \mathrm{He}$ wrote, "It is always necessary that the means that are to accomplish any end be equal to the accomplishment of that end." 34 If God desired human beings to know and obey him, he would make the means to achieve this end accessible to everyone. This point comported with Paine's criteria for religious truth consisting in equality and universality: "A thing which everybody is required to believe requires that the proof and evidence of it should be equal to all, and universal." 35 Hence, Paine's goal was to condense theology into universal beliefs that everyone could affirm.

Paine thus dismissed any revelation through human testimony as a discriminatory and mythological fabrication. Human means were finite and therefore inadequate to make any revelation known to everyone: "human language, more especially as there is not a universal language, is incapable of being used as a universal means of unchangeable and uniform information and therefore it is not the means that God useth in manifesting himself universally to man."36 On the basis

\footnotetext{
32 Paine, Age of Reason, 267.

33 This first section requires more elaboration than the others since Paine largely built his other religious views on his egalitarian epistemology of revelation.

${ }^{34}$ Paine, Age of Reason, 287.

35 Ibid., 272.

36 Ibid., 287.
} 
of his universal and democratic criteria, Paine discredited the Jewish Scriptures, the Christian Bible, the Muslim Quran, and every other oral, written, or illustrated revelation claiming divine origin. ${ }^{37}$ These forms of revelation are confined to human language, which "is local and changeable." 38 Paine rejected Christianity because it undemocratically boasted special revelation. The "idea that God sent Jesus Christ to publish [...] the glad tidings to all nations" struck Paine as cockamamie, for "how was Jesus Christ to make anything known to all nations?" 39 Paine protested that Jesus did not speak all the world languages, and if he had, the process of translation would have altered the message. Even more, no one was present to corroborate the verity of the virgin birth, and although the resurrection "admitted of public and ocular demonstration," it still "falls to the ground because that evidence was never" reported to everyone, everywhere, at all times. ${ }^{40}$ "Now, had the news of salvation by Jesus Christ been inscribed on the face of the sun and the moon, in characters that all nations would have understood," Paine explained, then "the whole earth had known it in twenty-four hours, and all nations would have believed it." But still after 2,000 years, the vast majority of the world knows nothing of Jesus Christ's salvation. ${ }^{41}$

Thus, Paine eschewed the notion of oral and written divine revelation and believed that knowledge of religious belief and practice must be equally attainable through natural human faculties. ${ }^{42}$ Echoing the American Declaration of Independence, Paine based his assertion of religious truth on self-evidence: "The nations who never heard of such books, nor of such people as Jews, Christians, or Mahometans, believe the existence of God as fully as we do, because it is self-evident." 43 What God has revealed about himself, such as his existence, he has made self-evident and therefore equally perceivable to all. Since God created all humankind with the same natural faculties, everyone has equal natural ability to discover universal self-evident

37 Ibid., 269.

38 Ibid., 286.

39 Ibid.

40 Ibid., 271-72.

41 Thomas Paine, An Examination of the Passages in the New Testament Quoted From the Old, and Called Prophecies of The Coming of Jesus Christ, in The Complete Religious and Theological Works of Thomas Paine (New York: Peter Eckler, Publisher, 1892), 249.

42 Paine's egalitarian vision for knowledge was sometimes imaginatively consistent, believing that even aliens enjoyed equal access to knowledge: "The inhabitants of each of the worlds of which our solar system is composed, enjoy the same opportunities for knowledge as we do." Paine, Age of Reason, 308.

43 Thomas Paine, Of the Religion of Deism, in The Complete Religious and Theological Works of Thomas Paine (New York: Peter Eckler, 1892), 399. 
revelation. ${ }^{44}$ The natural faculty that ascertained these self-evident religious truths was reason: "it is only by the exercise of reason that man can discover God." 45 Reason, "the choicest gift of God to man," was a natural faculty endowed to every human being at creation. ${ }^{46}$ While a few privileged believers could enjoy exclusive revelations by utilizing their spatial and linguistic similarities, everyone in the world had reason at their disposal. For Paine, reason was the "faculty by which [mankind] is enabled to contemplate the power, wisdom and goodness of the Creator displayed in the creation." 47 Paine did not need institutions, books, or witnesses to determine or uncover religious belief for him. In a thoroughly democratic, individualistic axiom he asserted, "my own mind is my church." 48

While reason was the universal tool for religious knowledge, creation was the universal object, "THE WORD OF GOD IS THE CREATION WE BEHOLD; and it is in this word, which no human invention can counterfeit or alter, that God speaketh universally to man." 49 For Paine, if anyone employed his or her reason and observed creation anywhere at anytime, they could deduce the two most fundamental religious beliefs: the existence of a Creator and the equality of mankind. ${ }^{50}$ Thus, reason and creation were God's universal means to accomplish universal ends: to indiscriminately make his existence known to all.

Second, Paine's egalitarian and universal criteria determined his understanding of God's character. As Ian Harris explains, "The God of Thomas Paine was impartial and His impartiality was used to prove that nature authorised no morally or politically significant distinctions among persons." 51 On the one hand, Paine claimed to have grounded human equality in the Creator and giver of natural rights. But on the other hand, as Harris suggests, Paine conformed his understanding of God to his anthropology: "Paine developed motifs about nature in relation to politics, and a view about God to explain them." 52 Paine posited a God who not only squared with his egalitarian anthropology but also legitimated and sanctioned it.

\footnotetext{
${ }^{44}$ As Ian Harris notes, "Paine pictured God as creating no distinctions by natural processes." See Harris, "Paine and Burke," 44.

45 Paine, Age of Reason, 288.

${ }^{46}$ Ibid., 286.

47 Paine, Of the Religion of Deism, 404.

48 Paine, Age of Reason, 268.

49 Ibid., 286. Emphasis original.

${ }^{50}$ Paine reproduced forms of the cosmological and ontological arguments as ways of utilizing reason to arrive at religious truths. Ibid., 288-90.

${ }^{51}$ Harris, "Paine and Burke," 58.

52 Ibid., 44.
} 
For Paine, if God became involved in human affairs, he would have to do it for everyone. Thus, he adopted a traditional Deist view of God as transcendent and withdrawn from the details of world affairs. He described God's involvement with the world thus: "It is as if he had said to the inhabitants of this globe that we call ours: 'I rendered the starry heavens visible, to teach him science and the arts. $\mathrm{He}$ can now provide for his own comfort, AND LEARN FROM MY MUNIFICENCE TO BE KIND TO EACH OTHER.' "53 God created men and women with equal access to knowledge about their existence and moral duties, and he removed his presence to allow humankind to exercise their reason freely.

Paine aggressively opposed the traditional Christian doctrine of the Trinity, frequently stressing that God was one single being. One of the main goals of his religious revolution was to "return [man] to the pure, unmixed, and unadulterated belief of one God, and no more." 54 Paine's insistence on one God did not originate directly from his scientific study of nature but rather from his egalitarianism. While people worldwide varied in the number of gods they affirmed, everyone could employ their natural faculties and acknowledge at least one God. Paine aimed to reduce religious knowledge to universal facts; therefore, he affirmed the singularity of God as a universal common denominator. Paine derived his egalitarian view of God from his view of religious knowledge: he would only identify traits about God that he believed could be universally known. One arrived at a knowledge of God through contemplating creation and reflecting with his or her reason. This process led Paine to conclude that God was truthful, just, merciful, good, moral, benevolent, powerful, and wise. He suggested that "Deism" taught him "that God is a God of truth and justice." 55 The just God "acts benignly towards all." 56 Paine charged the view of God as one who limits his benefits to some and not others as inequitable and unjust: "Paine's God is nothing if not evenhanded." 57

Paine even democratized worship of God. Christians studied their Bibles not only for knowledge about God but also as a devotional book. Paine read creation the same way: "contemplation of the works of creation" constituted his "devotional study." 58 Paine deemed worship of God on the basis of special revelation or redemptive acts no true worship at all, because it adored a God of partiality and fantasy.

\footnotetext{
53 Paine, Age of Reason, 294.

54 Ibid., 268.

55 Thomas Paine, Examination of Prophecies (1807), in The Writings of Tom Paine, ed. Moncure Daniel Conway, 4 vols. (New York: G. P. Putnam's Sons, 1894), IV, 357.

56 Paine, Age of Reason, 311.

57 Harris, "Paine and Burke," 53.

58 Paine, Age of Reason, 291-92.
} 
Instead, the "only idea we can have of serving God is that of contributing to the happiness of the living creation that God has made." ${ }^{9}$ True worship of God entailed imitating his impartiality and benevolence by serving and profiting humankind.

Third, Paine's view of redemption also conformed to his egalitarian criteria. Paine rejected all forms of religious redemption for two reasons. First, redemption was unnecessary because humankind never fell from its original state. Men and women still possessed all the same natural faculties and rights as when they were created, and man "stands in the same relative condition with his Maker [...] since man existed." 60 Thus, human beings needed no redemption from sin, nor did they need restoration to their Creator. Second, Paine believed that any external mediation between God and human beings undermined reason and humanity. Christianity could not provide universal redemption because not everyone could know about it. The only sufficient "mediation" between God and human beings was universal reason. The notion that God would redeem some and not others struck Paine as appallingly unfair.

Paine perceived the notion of redemption as proof that abusive religious authorities invented the doctrine as a ploy for unfair gain. ${ }^{61}$ Christians "fabricated" the doctrine of redemption in order to justify their "secondary and pecuniary redemptions," Paine asserted. ${ }^{62}$ The church based redemption on "a mere pecuniary idea corresponding to that of a debt," rather than upon "moral justice." 63 On the basis of the idea that Christ redeemed human beings by paying their debt, the church invented "secondary" redemptions through "the selling of pardons, dispensations, and indulgences" to those who would pay money on behalf of their sinful debts or of their loved ones. ${ }^{64}$ Paine thus rejected the doctrine of redemption as a prop for religious oppression and inequity.

Lastly, Paine's egalitarian and universal criteria determined his views on morality. He submitted that the "spirit of universal justice" should "preside equally over all mankind." 65 As Paine professed in the second and last article of his religious creed, "human equality" grounded "religious duties" to perform "justice" and "loving

\footnotetext{
59 Ibid., 311.

${ }^{60}$ Ibid., 285.

${ }^{61} \mathrm{He}$ actually examines certain Roman Catholic ideas of redemption, which most of his Protestant readers would also consider doctrinally erroneous.

62 Ibid., 284.

63 Ibid., 285.

${ }^{64}$ Ibid.

65 Thomas Paine, Public Good (1780), in The Writings of Tom Paine, ed. Moncure Daniel Conway, 4 vols. (New York: G. P. Putnam's Sons, 1894), II, 35.
} 
mercy" for the purpose of making "our fellow creatures happy."66 Paine rested the standard of morality in a nondiscriminatory benevolent God: "the practice of moral truth, or in other words a practical imitation of the moral goodness of God, is no other than our acting towards each other as he acts benignly towards all." 67 Human moral duty consisted of emulating God's impartiality and munificence.

Since special revelations suffered spatial and linguistic limitations, Paine did not think it was fair to impose their laws and principles as moral duties on all humankind. However, if universal creation or reason revealed a moral principle, everyone had the obligation to follow it: "Religion, considered as a duty, is incumbent upon every living soul alike and, therefore, must be on a level to the understanding and comprehension of all." 68 Men and women learned their moral responsibilities in the same way that they ascertained knowledge of God: through reason and observation of nature. Creation revealed what humankind needed to know about the moral goodness of God so that everyone would learn to imitate it: "Moral principle speaks universally for itself." 69 Reason instructed men and women that revenge, persecution, and cruelty violate moral duty, while mercy and justice harmonize with divine goodness. ${ }^{70}$

Paine's model for human morality was Jesus Christ: "He preached most excellent morality, and the equality of man."71 Paine maintained that Jesus never claimed to be God or to possess supernatural powers - the New Testament writers invented these beliefs. Paine's Jesus was no Savior but a humanitarian extraordinaire: “Jesus Christ founded no new system. He called men to the practice of moral virtues, and the belief of one God. The great trait in his character is philanthropy."72 The egalitarian, rational, and philanthropic Jesus of Thomas Paine embodied pure religion.

\section{Conclusion}

Although Paine reached dramatically different theological conclusions than his late eighteenth- and early nineteenth-century Protestant contemporaries especially evangelicals - their separate visions for reforming religion contributed to the same overall democratization of religious authority in nineteenth-century

\footnotetext{
66 Paine, Age of Reason, 267.

67 Ibid., 311.

68 Ibid.

69 Ibid., 315.

70 Ibid., 317.

71 Ibid., 272.

72 Ibid., 282.
} 
America. Both groups empowered lay believers by reframing theology and practice around themes of God's moral government, equality by creation, moral agency, liberty, and an optimistic view of natural human abilities like common sense and reason. Even though Paine's The Age of Reason was largely lambasted in the early Republic, many of its democratic religious impulses and presuppositions reflected important similarities with its critics. Thus, a closer look at Paine's religious thought in this context provides a better explanation for how religious thinkers ranging from evangelicals to Deists simultaneously arose and prospered at the turn of the nineteenth century and beyond by adapting their beliefs to widespread cultural and intellectual democratic values.

\section{Biographical Note}

Ryan Hoselton is a doctoral student in American religious history at Universität Heidelberg. His dissertation deals with experiential knowledge and biblical exegesis in early American evangelicalism, focusing particularly on Cotton Mather and Jonathan Edwards.

E-mail: rhoselton@hca.uni-heidelberg.de 